This is the last draft of the article after the refereeing process and just before publication.

Hürol, Y., (2013) "Ethical Considerations for a better Collaboration between Architects and Structural Engineers- Design of Buildings with Reinforced Concrete Frame Systems in Earthquake Zones" Science and Engineering Ethics. Vol:20. No:2. pp.597-612. DOI 10.1007/s11948-013-9453-4.

\title{
Ethical Considerations for a better Collaboration between Architects and Structural Engineers - Design of Buildings with Reinforced Concrete Frame Systems in Earthquake Zones
}

Yonca Hurol

\section{Introduction}

Buildings with reinforced concrete frame systems form the majority of the buildings in the modern world. These buildings also have one of the highest earthquake collapse rates. It is also known that the majority of these collapses could have been prevented either by the architects or by the structural engineers (Hurol, Wilkinson, 2005). Providing suggestions to solve the problem of buildings with reinforced concrete frame structures also requires a practical analysis of conflicting values between the architects and structural engineers in order to increase the quality of the product of their collaboration. The conflict between the two professions is very frequently of an unethical nature. Thus, the focus of this article is the ethics of collaboration between architects and structural engineers.

There are various reasons for the value conflict between architects and structural engineers. The first of these reasons is the architects' lack of practical knowledge about structures and earthquake resistant design. There is a gap in the literature in respect of offering architects practical support in the designing of the structure of buildings with reinforced concrete frame systems. The literature related to this subject, in respect of building specifications and books on structures, is mostly directed towards structural engineers and not architects. Many books on structure which were prepared for architects (such as Howard, 1966; Lin, Stotesbury, 1981; Macdonald, 2001; Underwood, Chivini, 2007; Popovic, Tyas, 2004) usually contain approximate methods of analysis and do not have sufficient information about the practicality of the architectural structural design of the most common structure types. Structure courses in departments of architecture also share the same problem as the literature. There are also some nonmathematical structure books (such as Salvadori, 1981; Mainstone, 1975; Billington, 1983; Nervi, 1965), however they either describe good examples of various types of structures or explain the history of different systems. Some construction books (such as Ching, 2011) give graphical information about structures, but they mostly give readymade graphical solutions without explaining the reasoning behind them. On the other hand, architectural books on tectonics (such as Botticher, 1852; Semper, 1951; Sekler, 1965; Hartonian, 1994; Gregotti, 1996; Frampton, 2001) focus mostly on the aesthetics of space in relation to structures and materials, and only provide some architectural examples. Furthermore, earthquake resistant design is the least considered structural design issue within the literature of structures for architects and within the structure courses in architectural education. Unfortunately, it is very uncommon for architects to use structural solutions in an architectonic manner in respect of earthquakes. Arnold $(1982,1984)$ highlighted the effect of architectural configuration on seismic design. Charleson, Preston and Taylor (2001) give examples and discuss the many different ways in which earthquake resistant architecture can be achieved. Later in 2004 Charleson and Taylor again give some other examples of architectural projects in which the issue of earthquakes is highly conceptualized and used in an explicit visual manner. A very few architects highlight the responsibility of their profession in respect of endeavouring to ensure safe structures in the event of an earthquake. When T. Ando (1997) received the RIBA Gold Medal for Architecture, he stated that: "Returning to 
Kobe and visiting the site of the earthquake, the first thing that struck me was just how important a responsibility we architects have on the very basic level of providing safety and security for people. Of course architecture is also about aesthetics and beauty but we do have the responsibility of considering function as well..." Later he also explained how he considered the social and ecological problems which occur due to Kobe earthquake and the previous war.

The second reason in respect of the problem of contradiction between architects and structural engineers is the presence of many bad examples of reinforced concrete buildings in the building market. The existence of these buildings creates a falsely positive impression with many architects, who then believe that these bad designs are acceptable. (Hurol, Wilkinson, 2005) The third point in respect of the contradiction between architects and engineers depends on the differences in their consideration of the design criteria according to differing value systems. Architects should simultaneously consider the functional and aesthetical criteria as well as the economic criteria and safety requirements, whilst structural engineers should consider only the two latter criteria. (Pultar, 1997; 2000) The fourth point in respect of this matter of the contradiction between architects and engineers arises as a result of the presence of their different approaches to the criteria of economics. Some professionals prefer to achieve the optimum solution in respect of structural problems, whilst others believe that it is also worth paying for the aesthetic value of the building.

The above stated reasons which form the basis for the contradiction between architects and structural engineers demonstrate that there is a multidimensional complex problem due to a lack of knowledge concerning the practical architectural design of reinforced concrete frame systems and the presence of a contradiction between the different design values. In order to resolve the problem of the lack of knowledge, the mathematical knowledge of structural engineering should be translated into the practical language of design in architecture. Closing the gap between theory and practice and making knowledge applicable is a required step towards better practice in general. This can be achieved by defining the steps of the architectural design of reinforced concrete structures in parallel with the structural problems requiring consideration during the actual design process. The problem due to the presence of different values in design cannot be solved by deciding according to the hierarchy of values, which gives priority to safety and economy, and then to functionality, and finally to aesthetics (Maslow, 1943; 1987), because architecture is based on the simultaneous presence of all these values. Thus, the value problem in the design of reinforced concrete frame systems can be further studied only by making these values more explicit through the analysis of different preferences in design.

The research objective of this article is to prepare a platform of professional consensus between architects and structural engineers by defining the initial steps in the architectural design process of reinforced concrete structures together with the structural problems which arise for consideration at each stage along with the consideration of the conflicting values in order to chose between alternative solutions which have different values. This is done by adapting Value Sensitive Design to the problem of structural design of reinforced concrete frame systems. The conclusion of the article contains some suggestions for a better collaboration between architects and structural engineers.

Since ethical problems should be considered according to the conditions within their context, and since structural form is often determined by the local practice based on the philosophy of local building regulations, this article will consider the conditions and earthquake policies present in Turkey. Since the Turkish earthquake regulations suggests the use of reinforced concrete frames with relatively thick columns (as thick as beams) as a lateral stability system rather than the use of shear walls for buildings of five storeys, this article also focuses on these types of buildings with reinforced concrete frame structures.

The methodology to collect and organize the data which is presented in this article is based on experience. The author of this article is an architect, who has an academic career in structural design and who has taught structure and architectural design simultaneously in many schools of architecture for nearly 30 years. During this time the author 
has monitored at least 300 students who were designing structures for their architectural projects. Thus, the author can, as a result of her extensive experience in this field, relate the values and problems of architecture and structural engineering to each other. Analysis of earthquake regulations, general knowledge about the limits and proportions of reinforced concrete frames and differing value systems of architects and structural engineers form the basis of data collection. This data is evaluated using the Value Sensitive Design by respecting the value systems of both professional groups and suggestions are made to include different value systems.

This article first gives some information about types of collaboration between architects and structural engineers. Then the criteria of structural design at various stages of structural design are presented and the values which affect each criterion are determined. The discussion of the results contains a selection of the appropriate methods for decision making and for the adoption and adaptation of the Value Sensitive Design to the structural design process of reinforced concrete frame systems.

\section{On Collaboration Between Architects and Structural Engineers}

"Collaboration leads to buildings possessing good seismic configuration and structure and architecture being wellintegrated." (Charleson, Pirie, 2009:92) Accrediting boards of many countries ask schools of structural engineering and architecture to train and teach their students in and about the process of collaboration. (ABET,2013; NAAB, 2013) On the other hand, an exemplary collaboration requires acceptance of professional value systems, a high level of technical and design skills, communication skills and well-developed personalities.

There are two main types of collaboration between architects and structural engineers. The first is realised after the design of the preliminary design project by the architect and its acceptance by the client. Before the application project is drawn up, the structural engineer is asked to design the structural system, which is already designed architecturally. The second type of collaboration is realised during the whole design process, including the preliminary design. This type of collaboration is usually realised within a multidisciplinary practice and for the design of monumental buildings rather than background buildings. For example, this type of collaboration is applied between Cecil Balmond and Ove Arup and Partners and within the practices of Libeskind, Koolhaus, Toyo Ito and UN Studio (Charleson, Taylor, 2004). The use of some computer programs, such as BIM, promise a better and more effective collaboration between the professionals involved. (Poerschke, Holland, Messner, Pihlak, 2009)

The most common type of collaboration between architects and structural engineers is the first type as described above. According to Felix Candela: "The second design phase... consists of a tremendous battle between the structural engineer and the architect... The result of the struggle is always the same: science prevails and the final design has generally lost the eventual charm, and end of detail dreamed by the architect." (Holgate, 1986 in Charleson, Pirie, 2009) However, today`s Postmodern world might cause some other problems due to the dominance of the architect.

Charleson and Pirie (2009:92) conducted a research into the issue of the complaints of architects and structural engineers about the collaboration between them. According to the results of this research: "Structural engineers' main concerns focus upon the following: architects`lack of structural understanding; architects`seeking structural advice too late for optimal structural solutions, and the need for architects in general to improve their focus upon collaboration. On the other hand, architects are disappointed by engineers`lack of both innovation and engagement with architectural design ideas."

This article suggests starting collaboration immediately after the conceptual design of the architectural project and before the preliminary project ends. This could, hopefully, eliminate engineers`complaints about architects` seeking advice too late and architects`complaints about engineers` lack of interest in architectural design ideas. However, unethical conflicts may still arise due to the contradictions between the different value systems, even if everything else is perfect. These types of conflicts can only be eliminated if the two sides can fully understand each other and this requires a value analysis of the criteria which can create conflict. 


\section{Criteria of Structural Design and Values which Determine their Use}

The criteria of earthquake resistant structural design of reinforced concrete frame systems up to 5 storeys, can be analyzed by using the earthquake regulations of different countries (in this case Turkey) and the general knowledge of designing such structures. These criteria can be grouped under the headings of:

- Geometric analysis of plan and placement of column axes,

- Selection of slab types,

- Design of cantilevers,

- Design of stair cases,

- Determining dimensions of columns and their design in the $3^{\text {rd }}$ dimension,

- Arrangement of columns in plan,

- Determining the sizes of galleries,

- Determining shape and dimension of beams,

- Arrangement of partition walls.

\section{Design of Frame Systems through Geometric Analysis of the Plan}

The early sketches of any architectural design should start by incorporating the initial decisions about the structure by analysing the plan, which shows the space boundaries (walls), according to the form of spaces it contains in order to place a column at every joint. This action should realize the requirement of ensuring linear or nonlinear continuity of column axes. (Ministry of Public Works..., 2007) This is required in order to achieve frame strengths capable of withstanding the horizontal forces of wind and earthquake loads. This criterion avoids the issue of having beams resting on other beams without having any columns to support the related joint. Although any intention against this criterion is dangerous, certain small deviations in it might be acceptable.

The column axes in a framed structure can be three types (Ministry of Public Works..., 2007):

- They can be linear and parallel to each other,

- They can be linear, but they might have different angles to each other,

- They might not be linear.

The first type is known as the best structural solution for withstanding horizontal forces. The second and the third types of axes can also be used in buildings and their use requires a change in the structural engineering calculations, which, in turn, causes an increase in the cost of the structural system of the building. (Ministry of Public Works..., 2007)

It is clear that preference between these axes types is related to the aesthetic requirements of design which causes an increase in the cost of the structure. Thus, if the column axes are of the second or third type, in order to avoid any unethical decisions the architect and the structural engineer should consider;

- If the client is ready to pay the difference in cost, or not,

- If the change in design decreases the artistic value of the project, or not.

It is logical to keep the axis system as it is, if the above conditions are met. If one of the conditions is not met, then a change of the axis system should be considered. Thus, the architect and the structural engineer can give an ethical 
decision by considering the economic preference and the budget of the client as well as the effect the structurally preferable solution will have on the artistic value of the project.

Whilst placing the columns and determining the shape and location of beams, the designers should also consider that any beams with a steep curvature create a torsion problem. The curved beams can only have a slight curvature. Although any intention against this criterion in respect of curved beams is dangerous, certain small deviations might be acceptable.

\section{Selection of Type of Slabs}

To choose the most appropriate slab type, the minimum length of each space in the plan should be measured and slab types should be chosen as follows (Lin, Stotesbury, 1981):

- If the span of the slab is under 7 metres, then simple reinforced concrete slab types can be used,

- If the span is over 7 metres and if the slab is rectangular, then ribbed slabs can be used,

- If the span is over 7 metres and if the slab shape is almost square, then waffle slabs can be used up to 15 metres,

- If the maximum slab dimension is over 15 metres, then it is better to divide the slab into two or more slabs, or to decrease the actual size of the slab. It is better to add shear walls to the system if the maximum slab dimensions are used.

The architect and the structural engineer can give an ethical decision about the slab type by considering the economic preference and the budget of the client as well as the effect of having the structurally preferable solution will have on the artistic value of the project.

If the slab type is ribbed or waffled, the length of the beams should be less than 10 metres maximum. However, it is more economic to limit the distance between columns to 4 to 7 metres. It is sometimes necessary to add intermediate columns in order to support the long beams. It is not necessary for these columns to be on the main column axes. If 10 meters of column distance is used, then it is better to add shear walls to the structure. Ignorance of the length of beams is dangerous.

\section{Design of Cantilevers}

The economic dimension of ordinary cantilevers can be around 2 or 2.5 meters. However some cantilevers in reinforced concrete frame buildings can span up to 8 or 9 meters, if they are supported by cantilevering beams. To give an ethical decision about the size and type of cantilevers the architect and the structural engineer should consider the economic preference and the budget of the client as well as the effect of having the structurally preferable solution on the artistic value of the project.

\section{Design of Staircases}

Flights of reinforced concrete staircases can be supported by a beam in the middle, or two beams with one beam at each side, or there may not be any beams. Beams of flights rest on the beams of the frame system and these beams should be supported by columns within the frame. The structure of the slabs adjacent to stairs should be checked to ensure that they are supported by a sufficient number of beams and columns. Although any intention against this criterion in respect of staircase design is dangerous, certain small deviations in it might be acceptable.

\section{Dimensions of Columns and their Arrangement in the third Dimension}

All vertical structural elements in a frame should reach the foundations in order to be able to transfer horizontal forces to the foundations. The dimensions of columns in a frame should be similar to the dimensions of the beams, in order to be able to resist any moment due to horizontal forces, or alternatively shear walls should be present in the 
system. According to Turkish regulations the column size should be similar to the beam size (Ministry of Public Works..., 2007), whilst according to Japanese specifications there should also be shear walls in the system (Paz, 1994). Nevertheless, the minimum column dimension according to Turkish specifications is $25 \mathrm{~cm}$ to $30 \mathrm{~cm}$ (Ministry of Public Works..., 2007). Although any intentional change in these criteria is dangerous, certain small deviations in them might be acceptable.

\section{Arrangement of Columns in Plan}

Outer columns should be perpendicular to the facade in order to increase the moment of inertia of the structure against horizontal forces. In order to make an ethical decision about the direction of the columns the architect and the structural engineer should consider the economic preference and the budget of the client as well as the effect the structurally preferable solution will have on the artistic value of the project.

Columns should be arranged (Ministry of Public Works..., 2007):

- Symmetrically on the plan in order to avoid twisting instability due to earthquakes or;

- They should be evenly distributed on the plan to minimize the eccentricity between a resultant earthquake force acting on the building and the resultant resistance of the building structure.

In order to make an ethical decision between the symmetrical arrangement and even distribution of vertical elements in a frame, the architect and the structural engineer should consider the economic preference and the budget of the client as well as the effect the structurally preferable solution will have on the artistic value of the project. However, ignorance in respect of the problem of twisting instability is dangerous in earthquake regions.

\section{Determining the Size of Galleries}

Slabs are expected to transmit the horizontal loads to the vertical elements in the frame. Thus, their area, shape and arrangement are important. The total area of galleries in a slab should be under $1 / 3$ of the total area of that slab. (Ministry of Public Works..., 2007) Although ignorance of the limitation in slab size is dangerous, small deviations might be acceptable.

\section{Determining Shape and Dimensions of Beams}

The depth of beams should be $1 / 10$ of their length. This value can be decreased to a certain extent by using wider beams. However, this makes the beams unnecessarily heavy and dangerous in respect of earthquakes. Using wide beams in earthquake regions is limited (Ministry of Public Works..., 2007).

\section{Arrangement of Partition Walls}

The location of non-structural walls is usually determined before positioning columns during the architectural design of a building with a reinforced concrete frame system. However, it is believed that it is possible to remove all types of partition walls within frame systems in order to make new interior arrangements in such buildings. This is a common application in interior design and there is not any policy, which limits changes in partition walls in order to avoid the danger of vertical irregularity problems due to earthquakes. Turkish earthquake specifications (Ministry of Public Works..., 2007) consider soft storey and short column irregularities only for the initial design and construction of buildings, but they do not subsequently follow any internal re-arrangements. For example, it is stated that columns, which are used within soft storeys and short columns, should be designed differently in comparison to the design of ordinary columns, which do not have these problems. However, some rigid partition walls maybe removed later and new ones freely re-located in the building, thus possibly creating new soft storeys and short columns, which were clearly not included for consideration during the initial structural engineering design. Since it is often a functional requirement in the life of people to make spatial changes (Habraken, 1998) and since people will continue 
to make changes in any case, ignorance of vertical irregularity problems due to future interior design changes in earthquake policies is not ethical. Thus, in this part of this article the analysis of structural requirements due to the arrangement of partition walls will not be carried out according to the criteria set within Turkish earthquake specifications. The author prefers to consider policies of some other countries in order to avoid future dangers as well as the present ones.

To avoid present and future vertical irregularity problems in a building with a reinforced concrete frame system and rigid partition walls, one of the following solutions can be employed (Ambrose, Vergun, 1999; Athanassiadou, 2008; Kaushik, Rai, Jain, 2009; Kirac, Dogan, Ozbasaran, 2011; Lee, Woo, 2002):

- Shear walls can be used to resist horizontal forces,

- Elastic materials can be put in between the structural elements and the rigid partition walls in order to eliminate the restriction of movement of the beams and columns by the partition walls,

- All floors can be designed as soft floors and all columns can be designed as short columns by the structural engineer,

- Lightweight partition walls might be preferred to eliminate the problem which originates from the rigidity of the partition walls.

The first precaution against vertical irregularity problems is accepted by the Japanese policy regulations in respect of earthquakes, whilst the second one is accepted by the Mexican policy regulations. (Paz, 1994) Although ignorance of present and future vertical irregularity problems is dangerous, small deviations might be acceptable.

If rigid partition walls are planned in the design of the system, they should be located on the column axes, otherwise they exert a concentrated load on the slabs which support them. Although ignorance of the position of rigid partition walls is dangerous, small deviations might be acceptable.

\section{Discussion of Results in order to solve the Value Conflicts in Collaboration}

According to the analysis of the structural design criteria of reinforced concrete frame systems within this article, it can be stated that the stages of structural design within architectural design are as follows:

1. Decisions about the structural system selection are made in parallel to the development of the initial ideas/plans for the building.

2. Decisions about the location of partition walls are made before knowing the exact location of columns. The arrangement of columns and column axes is effected by considering the initial positioning of partition walls.

3. Dimensions of structural elements are given.

4. The system is checked against possible twisting instability and vertical instability problems in the event of earthquake activity.

Table 1 shows the different stages in the structural design of reinforced concrete frame systems, the criteria of design at every stage, the conflicting values affecting the decision about them and the tolerances of each design criteria together.

\begin{tabular}{|l|l|l|l|}
\hline Stages of structural design & Criteria of structural design & $\begin{array}{l}\text { Determining } \\
\text { value }\end{array}$ & $\begin{array}{l}\text { Toleran } \\
\text { ce }\end{array}$ \\
\hline $\begin{array}{l}\text { Initial concept of the building } \\
+ \text { structural system selection }\end{array}$ & $\begin{array}{l}\text { Reinforced concrete frame systems should be less } \\
\text { than 15 floors. }\end{array}$ & $\begin{array}{l}\text { Economy, } \\
\text { aesthetics }\end{array}$ & Larger \\
\cline { 2 - 4 } & $\begin{array}{l}\text { Maximum length of beams should be around 10 } \\
\text { metres. }\end{array}$ & Safety & Little \\
\cline { 2 - 4 } & Slab size should not exceed 20 metres. & Economy & Larger \\
\hline $\begin{array}{l}\text { Determination of space } \\
\text { boundaries (location of walls) }\end{array}$ & $\begin{array}{l}\text { Column axes should have linear or non-linear } \\
\text { continuity. }\end{array}$ & Safety & Little \\
\hline
\end{tabular}




\begin{tabular}{|c|c|c|c|}
\hline \multirow{8}{*}{$\begin{array}{l}\text { + arrangement of column axes } \\
\text { (including cantilevers, stairs } \\
\text { and slabs) }\end{array}$} & Shape of column axes should be considered. & $\begin{array}{l}\text { Economy, } \\
\text { aesthetics }\end{array}$ & Larger \\
\hline & Rigid partition walls should be on column axes. & Safety & Little \\
\hline & Curvature of beams cannot be steep. & Safety & Little \\
\hline & $\begin{array}{l}\text { If there are shear walls, they should be } \\
\text { constructed in at least two directions. }\end{array}$ & Safety & Little \\
\hline & Sizes of cantilevers should be considered. & $\begin{array}{l}\text { Economy, } \\
\text { aesthetics }\end{array}$ & Larger \\
\hline & Selection of slab types should be considered. & $\begin{array}{l}\text { Economy, } \\
\text { aesthetics }\end{array}$ & Larger \\
\hline & $\begin{array}{l}\text { Total area of galleries in a slab should be under } \\
1 / 3 \text { of total area of that slab. }\end{array}$ & Safety & Little \\
\hline & Structural design of stairs should be considered. & Safety & Little \\
\hline \multirow[t]{3}{*}{$\begin{array}{l}\text { Giving dimensions to all } \\
\text { structural members. }\end{array}$} & $\begin{array}{l}\text { Columns sizes should be similar to the sizes of } \\
\text { beams. Minimum column size should be } 25 \times 30 \\
\mathrm{~cm} \text {. }\end{array}$ & Safety & Little \\
\hline & $\begin{array}{l}\text { Outer columns directions should be perpendicular } \\
\text { to the facade. }\end{array}$ & $\begin{array}{l}\text { Economy, } \\
\text { aesthetics }\end{array}$ & Larger \\
\hline & $\begin{array}{l}\text { Limitation in the use of wide beams should be } \\
\text { considered. }\end{array}$ & Safety & Little \\
\hline \multirow{2}{*}{$\begin{array}{l}\text { Checking twisting instability } \\
\text { and vertical irregularity } \\
\text { problems. }\end{array}$} & Twisting instability problem should be resolved. & Safety & Little \\
\hline & $\begin{array}{l}\text { Present and future vertical irregularity problems } \\
\text { should be resolved. }\end{array}$ & Safety & Little \\
\hline
\end{tabular}

Table 1. Stages of design of reinforced concrete frame systems, criteria of design, conflicting values determining decisions about them and tolerances of these criteria.

Table 1 contains two types of value conflict for the application of criteria in respect of the structural design of reinforced concrete frame systems. These are:

- Between safety and aesthetics (and sometimes functionality): These criteria are usually taken from earthquake regulations. It is dangerous to avoid these criteria and thus they have little tolerance.

- Between economy and aesthetics (and sometimes functionality): These criteria are usually taken from the general knowledge base about reinforced concrete frame systems. The preferences and budget of the client have to be considered as does the effect of any change on the artistic value of the building. This value conflict gives a greater tolerance for the application of the criterion.

It is necessary to make a judgement for each value conflict during a collaborative design. According to Charleson and Pirie (2009) engineers usually have a hierarchical value system, whilst architects usually have a non-hierarchical one; Engineers aim for the correct solution, whilst architects produce infinite possibilities; Engineering design is based on analysis, whilst architectural design is based on synthesis. However, this might not be the case and there can be other value systems, beliefs and personality traits, which increase the number of possibilities for both professions. Bucciarelli (2000) explains the situation of different professionals with different value systems with the help of a game called Delta Design, which involves different professions making the same plan for an abstract creature. He says that different professionals have different "object worlds." According to him: "Different participants working within different object worlds, see the same object of design yet see it as something different."

Frassen`s (2005) Arrow`s theorem, which is used to select between various alternatives by evaluating them according to multiple criteria, is not applicable for the value conflicts between architects and structural engineers, if there is only one architectural project to develop. Even if there are alternative design projects, architects usually choose one of them as their favourite. The only way of solving the value conflicts between architects and structural 
engineers is to develop the design project further by understanding each other. Value Sensitive Design can be useful in terms of supporting architects and structural engineers to understand each other. (Friedman, Kahn, Borning, 2006; Schuler, 2004; Le Dantec, Poole, Wyche, 2009) Depending on the process described by Friedman, Kahn and Borning (2006) Value Sensitive Design can be adapted to structural design processes as follows:

- Start with a Value, Technology or Context of Use: Design of reinforced concrete frame systems.

- Identify direct and indirect stakeholders: The client can be defined as the direct stakeholder and others including the architect and the structural engineer can be defined as indirect stakeholders. Priority should be given to the direct stakeholders.

- Identify benefits and harms: Structural design criteria in Table 1 shows the possible harms to the structure and the building.

- Map benefits and harms onto corresponding values: Architectural and structural engineering values related to each design criteria are also shown in Table 1.

- Determine the key values: According to Le Dantec, Poole and Wyche (2009) values with ethical import (such as human welfare) can be privileged or some other values can be added to the list of privileged values depending on the value systems of the client, architect and the structural engineer.

- Identify potential value conflicts: Table 1 shows a list of possible value conflicts in structural design. However, each design process results in the determination of particular value conflicts.

- Develop the design in order to solve the value conflict: The architect considers the structural problems and develops the design in order to achieve a safe structure without losing the qualities of the architecture.

In order to give an example of value conflicts between architects and structural engineers it is possible to imagine how each professional would think and behave. If the structural engineer has a hierarchical value system, according to him/her the first type of value conflict, which arises between safety and aesthetics (and functionality) can be resolved by making the necessary changes to achieve safety and the requirement of aesthetics (and functionality) is not that important. In the hierarchical value system architectural values can be listed from the most important to the least important as: safety, economy, functionality and aesthetics. Thus, the second type of value conflict can also be resolved by making the necessary changes to achieve economy and ignoring the issue of aesthetics. Although the ethical rule of recognition of the value system of other professionals should prevent the issue of dominance arising on all sides, this engineer would not understand the requirement of aesthetics.

If the architect has a value system, which requires that safety, functionality and aesthetics are achieved simultaneously, the only architectural way of solving the first type of conflict is to meet the safety and aesthetics requirements simultaneously and this implies, therefore, a revision of the design project. If it is not possible to reach a solution, which satisfies both safety and aesthetics requirements, only then is the criterion applied which ignores the aesthetics. However, this spells `failure` for the architectural project. This is the famous value system suggested by Vitruvius (translation in 1960) as "firmitas, utilitas, venustas" (solid, useful and beautiful). According to this value system, architectural solution to the second type of value conflict depends on the clients preference. If the budget of the client is tight, then both of the economical and aesthetic requirements should be achieved simultaneously. This means that a revision of the project is necessary. Again the requirement of economy should not prevail over aesthetics. If it is not possible to produce an alternative in which both values are satisfied, then economy will, however, prevail over aesthetics. However, this again means failure for the architectural project. If the budget of the client is not tight, then the aesthetics requirement can prevail over the economical requirement, because clients' preferences should always have a priority. Being in collaboration with the above described structural engineer, this architect would have difficulties in getting professional support while developing a design to achieve safety and 
aesthetics simultaneously. S/he would expect the structural engineer to be more innovative to help him/her to achieve the original design idea.

These two professionals cannot understand each other. However the use of Value Sensitive Design can show them the above picture very clearly. In the case of a conflict as between the architect and the structural engineer, it might also be useful to avoid the problem of many hands and to identify a responsible person (Doorn, 2012), who has a more demanding value system. In this case the architect has a more demanding value system. Since the professional value system of architecture is usually more demanding then the professional value systems of other professions within the building team, architects are usually seen as the leaders of building teams. This also means that architects should always consider structural engineering criticisms to be on the more demanding side. The policies of many countries see architects as responsible for all types of problems which occur in the buildings they design together with the other related professionals. This means that if a building collapses as the result of an earthquake, then both its architect and the structural engineer can be held culpable.

However, personal approaches to values and different beliefs might change the whole picture. Whatever is the case, understanding each others`value systems through Value Sensitive Design and selection of the more demanding professional as the team leader can lead towards a solution of the conflict.

\section{Conclusion}

The different approaches of architects and structural engineers to structural design along with their different value systems usually clash during the decision making processes. For example, the positioning of partition walls must be decided before deciding on the location of columns. Actually, the location of the columns is decided according to the positioning of the partition walls in architectural design. Conversely, structural engineering logic expects to place the columns first and then the partition walls. Since the initial designer of the structure is the architect, structural design phases are adapted to the phases of architectural design. Nevertheless, the structural design criteria are borrowed from structural engineering and most of the values, which affect the decision making, are structural engineering values, such as safety and economy. The research objective of this article is to prepare a platform of agreement for architects and structural engineers by defining the stages of architectural design of reinforced concrete frame systems in parallel to the structural design criteria and the conflicting values required to make decisions about each stage.

Using Value Sensitive Design during collaboration and selecting the more demanding person as the leader of the team, guarantees achieving the maximum level of values. The ideal case requires the achievement of all values simultaneously.

All phases of structural design contain at least one structural design criteria, which creates a value conflict between safety and aesthetics (or functionality) Although these criteria have little tolerance, the requirement of aesthetics should also be satisfied according to the ideal approach. Conversely, all phases of structural design (except the last phase of control) contain at least one structural design criteria, which causes value conflict between economy and aesthetics (and functionality). Although these criteria have a greater tolerance, the decision depends on the preference of the client. If the budget of the client is tight, both economic and aesthetic requirements should be satisfied according to the ideal approach. However, if the client's budget is not tight, then only the aesthetic requirement can be satisfied.

The structural design of reinforced concrete frame systems is a complex decision making process which requires the consideration of various and sometimes contradictory values. This article suggests that architects and structural engineers start to collaborate immediately after the conceptual design phase, and before the end of the preliminary project. If architects and structural engineers agree on using Value Sensitive Design and choose a team leader with demanding values, then they can solve the value conflicts in a healthy way, realize a good collaboration and achieve a successful design project. 


\section{REFERENCES}

ABET (Accreditaion Board for Engineering and Technology) (2013) Accreditation criteria available online: http://www.abet.org/accreditation-criteria-policies-documents/ Last accessed: April 2013.

Ambrose, J.,Vergun, D., (1999). Design for Earthquakes. Canada: John Wiley and Sons Inc.

Ando, T., (1997) “Tadao Ando’s Royal Gold Medal Address.” Concrete Quarterly. Autumn. pp.2-7.

Arnold, C., Reitherman, R., (1982) Building Configuration and Seismic Design - The Architecture of Earthquake Resistance. Wiley.

Arnold, C., (1984) "Building Configuration: The Architecture of Seismic Design." Bulletin of the New Zealand National Society for Earthquake Engineering. 17(2) pp.83-89.

Athanassiadou, C.J., (2008) "Seismic performance of R/C plane frames irregular in elevation." Engineering Structures. 30(5) pp.1250-1261.

Billington, D. P., (1983) The Tower and Bridge, NY: Basic Book Publishers.

Botticher, K. (1852) The tectonics of the Hellenes. Postdam.

Bucciarelli, L.L., (2000) "Delta Design: Seeing / Seeing As." Proceedings of the 4th Design Thinking Research Symposium on Design Representation, MIT, April 1999.

Charleson, A., Preston, J., Taylor, M., (2001) "Architectural Expression of Seismic Strengthening." Earthquake Spectra. 17(3) pp.417-425.

Charleson, A., Taylor, M., (2004) "Earthquake Architecture Explorations." 13th World Conference on Earthquake Engineering. Vancouver. Canada 1-6 August 2004. Paper no: 596.

Charleson, A.W., Pirie, S., (2009) “An Investigation of Structural Engineer - Architect Collaboration.” SESOC Journal (New Zealand) 22(1) pp.97-104.

Ching, F.D.K., (2011) Building Construction Illustrated. John Wiley and Sons.

Crane, T., (1956) Architectural Construction. $2^{\text {nd }}$ Edition. NY: John Wiley and Sons.

Doorn,N., (2012) "Exploring Responsibility Rationales in Research and Development." Science Technology Human Values. 37: 180. http://sth.sagepub.com/content/37/3/180 (accessed in April 2013)

Frampton, K., (2001) Studies in Tectonic Culture: The Poetics of Construction in Nineteenth and Twentieth Century Architecture. Ed: J. Cava. Cambridge, Massachusets: The MIT Press.

Frassen, M., (2005) “Arrow's Theorem, Multi-criteria Decision Problems and Multi-attribute Preferences in Engineering Design.” Research in Engineering Design. 16. pp.42-56.

Friedman, B., Kahn, P., Borning, A. (2006) "Value Sensitive Design and Information Systems." Zhang, P., Galletta, D. (Eds.) Human Computer Interaction in Management Information Systems. NY: M.E. Sharpe Inc. pp. 1-27. 
Gregotti, V (1996) "The exercise of detailing," in K. Nesbitt (Ed.) Theorizing a new agenda for Architecture: an anthology of architecture theory 1965e1995, NY: Princeton Architectural Press. pp. 494-497.

Habraken, J., (1998) The Structure of the Ordinary - Form and Control in The Built Environment. J.Teicher (Ed.). Cambridge Massachusets: The MIT Press.

Hartoonian, G., (1994) Ontology of Construction. New York: Cambridge University Press.

Holgate, A., (1986) The Art in Structural Design. Clarendon Press.

Howard, H.S., (1966) Structure: An Architects Approach. NY: Mc Graw Hill Book Company.

Hürol,Y., Wilkinson, N., (2005) "A Critique of Earthquake Policies of Northern Cyprus." Proceedings of the Institution of Civil Engineering-Structure and Buildings. 158(6) pp.355-369.

Kaushik H.B., Rai D.C., Jain S.K., (2009) "Effectiveness of some strengthening options for masonry infilled RC frames with open first storey.” Journal of Structural Engineering- ASCE. 135(8) pp.925-937.

Kirac N., Dogan M., Ozbasaran H., (2011) "Failure of weak storeys during earthquakes." Engineering Failure Analysis. 18(2) pp. 572-581.

Le Dantec, C.A., Poole, E.S., Wyche, S.P., (2009) "Values as Lived Experience: Evolving Value Sensitive Design in Support of Value Discovery." Proceedings of the SIGCHI Conference on Human Factors in Computing Systems. ACM.

Lee,H.S., Woo,S.W., (2002) "Effect of Masonry Infills on Seismic Performance of a 3 Storey R/C Frame with Nonseismic Detailing.” Earthquake Engineering Structures. 31 (2) February. p.353.

Lin, T.Y., Stotesbury, S.D., (1981) Structural Concepts and Systems for Architects and Engineers. NY: John Wiley and Sons.

Macdonald, A.J., (2001) Structure and Architecture. Routledge.

Mainstone, R., (1975) Developments in Structural Form. Massachusets: The MIT Press.

Maslow, A., (1943) A Theory of Human Motivation. Psychological Review. 50. Pp.370-396.

Maslow, A., (1987) Motivation and Personality. Third edition. NY: Harper and Row.

Ministry of Public Works and Settlement Government of the Republic of Turkey. (2007) Seismic Performance Evaluation of Dual Reinforced Concrete Systems Design According to Turkish Seismic Code. (Trans: E.Y. Karc1) http://www.belgeler.com/blg/22lc/seismic-performance-evaluation-of-dual-reinforced-concrete-systemsdesign-according-to-turkish-seismic-code

NAAB (National Architectural Accrediting Board) (2013) Accreditation criteria availbale online: http://www.naab.org/accreditation/ Last accessed: April 2013.

Nervi, P.L., (1965) Aesthetics and Technology in Building. Cambridge, Massachusets: Harvard University Press.

Paz, M., (1994). International Handbook of Earthquake Engineering. NY: Chapman \& Hall. 
Poerschke, V., Holland, R.J., Messner, J.I., Pihlak, M., (2009) "BIM Collaboration across six Disciplines." Tizami, W. (Ed.), Proceedings of the International Conference on Computing in Civil and Building Engineering. Nottingham: Nottingham University Press.

Popovic, L.O., Tyas, A., (2004) Conceptual Structural Design: Bridging the Gap Between Architects and Engineers. Thomas Telford.

Pultar, M., (1997) "A conceptual framework for values in the built environment." Evolving Environmental Ideals: Changing Ways of Life, Values and Design Practices. Ed: M. Grey. Stockholm: Royal Institute of Technology. pp.261-267.

Pultar, M., (2000) "The Conceptual Basis of Building Ethics." Ethics of the Built Environment. Ed: W. Fox. London: Routledge.

Salvadori, M., Levy, M., (1981) Structural Design in Architecture. Prentice Hall.

Schuler, D., (2004) Liberating Voices - A Pattern Language for Communication Revolution. Cambridge Massachusets: MIT Press. pp.366-369.

Sekler, E.F., (1965) "Structure, construction, tectonics." in Kepes, G. (Ed.) Structure in Art and in Science. NY: George Braziller. pp. 89-95.

Semper, G., (1951) The four elements of Architecture and Other Writings. NY: Cambridge University Press.

Underwood, J.R., Chivini, M., (2007) Structural Design: A Practical Guide for Architects. Wiley.

Vitruvius, P., (transl. M. H. Morgan, 1960) The Ten Books on Architecture. Courier Dover Publications. 